\title{
Clinical and Mental Health Issues in Counseling the Gifted Individual
}

Jennifer Riedl Cross

College of William and Mary, jrcross@wm.edu

Tracy L. Cross

College of William and Mary, tlcross@wm.edu

Follow this and additional works at: https://scholarworks.wm.edu/educationpubs

Part of the Gifted Education Commons

\section{Recommended Citation}

Cross, Jennifer Riedl and Cross, Tracy L., Clinical and Mental Health Issues in Counseling the Gifted Individual (2015). Journal of Counseling \& Development, 93(2), 163-172.

https://doi.org/10.1002/j.1556-6676.2015.00192.x 


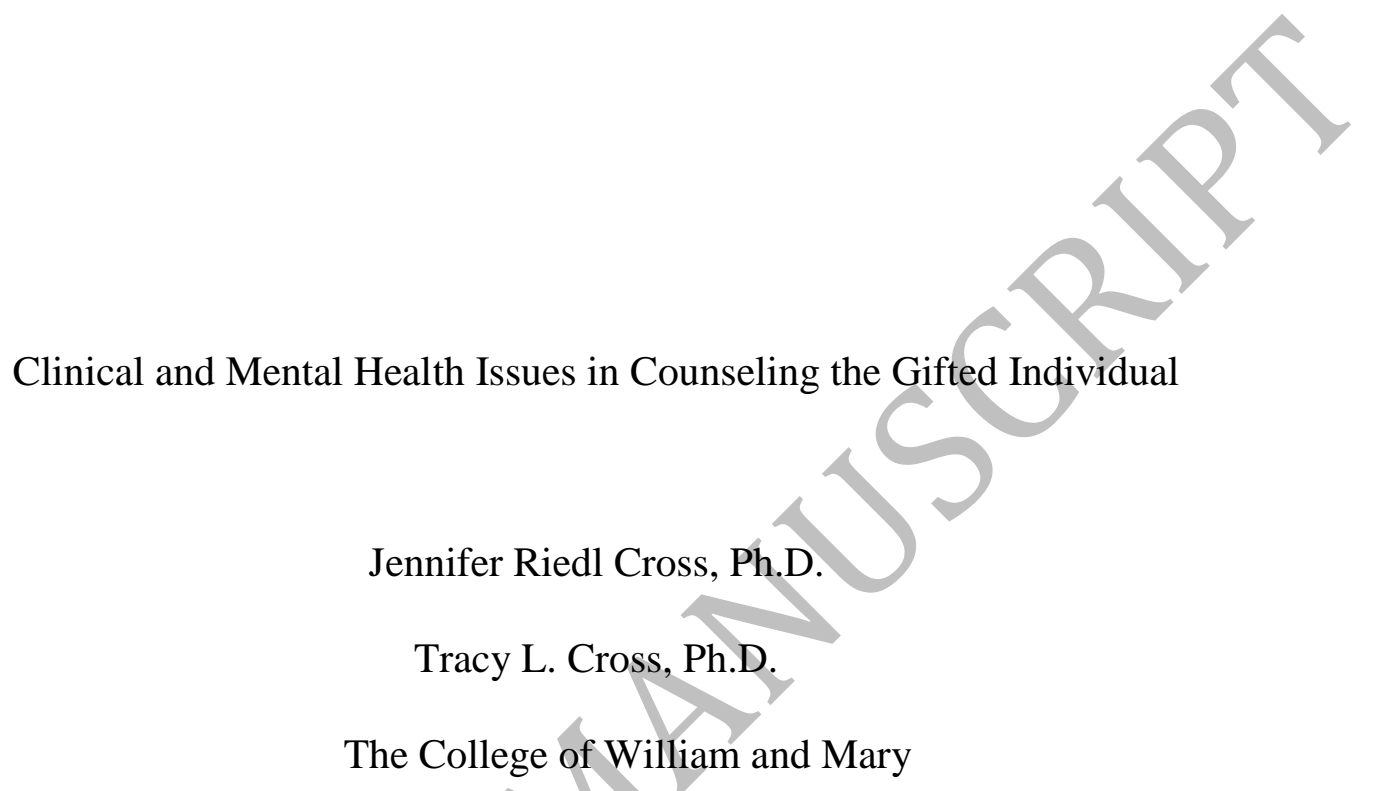

\section{Final version accepted for publication}

Cross, J. R., \& Cross, T. L. (2015). Clinical and mental health issues in counseling the gifted individual. Journal of Counseling \& Development, 93, 163-172. 


\begin{abstract}
Research over the past several decades identified a number of unique characteristics and experiences of gifted individuals that have implications for counselors. This article describes internal and external factors that contribute to a non-normal lived experience and that may require counselors' specific attention in order to work effectively with gifted clients on clinical issues. These factors are applied to four issues: 1) unhealthy perfectionism, 2) anxiety, 3) depression, and 4) suicidality.

Keywords: gifted, high ability, mental health issues
\end{abstract}


Clinical and Mental Health Issues in Counseling the Gifted Individual While there are a host of issues that can be addressed in terms of the clinical and mental health issues of gifted individuals, the focus of this article is on the unique experiences and characteristics of gifted individuals and how they are significant to four particular issues potentially faced by counselors in schools as well as mental health professionals in clinical settings: (a) unhealthy perfectionism, (b) anxiety, (c) depression, and (d) suicidality. Based on research among gifted individuals, it is possible to highlight characteristics or experiences that may be important to treatment of these conditions. By definition, gifted individuals are not normal on some metric, and this non-normality can manifest in unexpected responses to others or from others. Unfortunately, there is little research that clearly delineates differences in the incidence of mental health issues between gifted and nongifted subjects (Martin, Burns, \& Schonlau, 2010), in part because of a lack of consensus on a definition of giftedness. What research exists suggests that in many ways, gifted individuals have no higher incidence of mental disorders than their peers, with the exception of creatively gifted individuals (Neihart, 2012). Academically or intellectually gifted individuals may be no more likely than their peers to experience mental health disorders, but when they do, the precipitating or impacting factors may be related to their non-normality. Perhaps most important to understanding how these clinical and mental health issues should be approached with a gifted client is a recognition of the unique lived experience of these individuals.

\section{The Lived Experience of Gifted Individuals}

The exceptional abilities of gifted individuals contribute to divergent experiences, which may be academic, interpersonal, or intrapersonal. The lived experience - a term from phenomenological research used to describe "the world as we immediately experience it" (Van 
Manen, 1990, p. 9) — of gifted individuals can be dramatically different from that of their nongifted peers (Coleman, 2012; Coleman \& Cross, 1988, 2000), perhaps because of their processing of the experience or because of the differential treatment by others.

Some gifted students experience feelings of differentness from peers (Cross, Coleman, \& Stewart, 1995; Robinson, 1996). Cross et al. found gifted high school students who reported such feelings of differentness were more likely to respond truthfully about their exceptional abilities in a hypothetical scenario where their abilities would be exposed to others. These students allow their differences to be known, but other gifted adolescents would lie or divert the conversation to avoid exposure (Cross, Coleman, \& Terhaar-Yonkers, 1991). Such modified behavior provides evidence of the stigma that accompanies giftedness (Coleman, 1985). Unlike other stigmatizing conditions, giftedness can be hidden and gifted students sometimes feel the need to go underground in order to find acceptance. Especially in adolescence, such inauthenticity can present challenges to ego development. Recognizing the challenges of the gifted individual's unique lived experience is necessary for a counselor to fully understand a client's problem.

\section{Social Interaction}

Family relationships. Interactions with others make up an important part of one's lived experience. Family relationships may be affected differently for clients who have been identified as gifted and those who have not. Families may experience upheaval by a gifted identification; pursuit of an appropriate education may mean attendance in special programs (requiring transportation and expense) and sometimes even a physical move to be near a recommended program (Burney \& Cross, 2006). Having a gifted child who is very different in ability from siblings or even parents may result in a stressful situation for the family (Hermann \& Lawrence, 2012). Determining how to allocate resources among multiple siblings, not just financial, but 
including time and attention, can be a major challenge for parents. Developing gifted children incorporate these reactions into their ideas of who they are, particularly in relation to others; a source of pride, irritation, frustration, a catalyst. Parents may be unaware of the stress students experience as a result of their academic commitments. In their study of gifted students' experience of stress, Peterson, Duncan, and Canady (2009) found that academic pressures were the most frequently reported stressor and there was often a discrepancy between the parents' perceptions of significant stressors and the students' perceptions.

Families of gifted individuals tend to have similar characteristics. Counselors may learn over time with a client that his or her parents were very focused on achievement and success (Moon, Jurich, \& Feldhusen, 1998), having high standards and maybe even perfectionistic themselves (Schuler, 2000). Speirs Neumeister and Finch (2006) found that an authoritarian parenting style, particularly the mother's, was related to insecure attachment and perfectionism among honors college students. In some family environments, the pressure to achieve may be great, creating stress for the child, particularly when expectations are unrealistic (Webb, 1993).

On the other hand, families of gifted individuals are often stable and cohesive and responsive to the child's needs (Hermann \& Lawrence, 2012), perhaps ameliorating some of the problems surrounding pressure to achieve.

Peer relationships. Young gifted children, particularly gifted boys, tend to be popular among their peers (Farmer \& Hollowell, 1994; Luftig \& Nichols, 1990). Gifted girls were least liked in multiple studies (Luftig \& Nichols, 1990; Quatman \& Swanson, 2002). Meijs, Cillessen, Scholte, Segers, and Spijkerman (2008) found that popularity of the adolescents in their study could be predicted by an interaction between social intelligence and academic achievement, but not by achievement alone. As gifted individuals mature, the influence of their giftedness on peer 
relationships may become problematic. Attempts to manage information about themselves may be in response to the stigma associated with giftedness (Coleman, 1985), or in response to being the target of threatening upward comparisons (Exline \& Lobel, 1999). While Festinger (1954) proposed that downward comparisons, comparisons against those faring worse than the self, should lead to positive affect, this is not necessarily the case for those who are frequently superior performers (Exline \& Lobel, 1999), as gifted individuals tend to be. Instead, individuals may become sensitive to being the target of a threatening upward comparison, altering their behavior to reduce the threat they present to others, particularly others whose relationships they value. Conditions that make the outperformance salient for the outperformed, such as high stakes competition, can exacerbate the sensitivity felt by the gifted individual. Grobman (2009) reported that gifted clients had difficulty dealing with their abilities because of the perceived effect on others:

Well into adulthood, they held onto an irrational belief that when they succeeded in using their powerful intellect or artistic sensibility, it humiliated others: All accomplishments took place in a sort of gigantic zero sum game in which their "win" was someone else's loss. (pp. 116-117)

To maintain the social latitude they desire, gifted individuals may engage in social coping behaviors (Coleman \& Cross, 1988; Grobman, 2009). Coping behaviors may be problemfocused, such as hiding one's giftedness or engaging in extracurricular activities to steer attention away from their intellectual differences. These strategies are positively correlated with selfconcept (Swiatek, 2001), but emotion-focused coping behaviors such as denying one's giftedness or denying the impact it has on peer relationships are negatively associated with self-concept (Swiatek, 2001). Giftedness may pose a challenge to developing peer relationships (Cross, 2012). 
This can be especially troublesome when the gifted individual chooses not to achieve to his or her potential in order to satisfy the need for belonging, as evidenced in studies finding decreased grades directly linked to friends' grades or peer pressure (Berndt, 1999).

A gifted individual's asynchronous development may make it difficult for agemates to predict his or her behavior. The child who has highly developed intellectual abilities, yet has not learned emotion regulation is likely to be rejected by peers (Semrud-Clikeman, 2007). The missed opportunities for social learning in early peer relationships, due either to an exclusive focus on intellectual pursuits or to rejection by peers, can have a cascading effect on an individual's ability to relate to others. Perfectionism, particularly other-oriented perfectionism, may interfere with positive relationship building (Stoeber, 2013). The gifted individual who is hypercritical of others will have difficulty maintaining friendships. Overexcitabilities (Dabrowski, 1964), heightened sensitivities in intellectual, emotional, imaginational, sensory, or psychomotor domains, have been embraced by many in gifted education (e.g., Piechowski, 1999; Probst \& Piechowski, 2012) because they believe these differentiate gifted individuals from their peers. Mendaglio (2012) argues that this belief stems from a misinterpretation of Dabrowski's theory of positive disintegration and is not wholly supported by the theory. If the association between giftedness and overexcitabilities is true, however, this differentiation may come at a cost. Children are attracted to friends who are socially and demographically similar (Farmer \& Farmer, 1996), but it may be difficult to see similarity in a child who responds extremely to stimulation of various types. The same may be true of the high need for cognition (Cacioppo, Petty, \& Kao, 1984) individual surrounded by peers with a low need or of the individual with a preference for abstract thinking surrounded by peers who prefer concrete experiences (Cross, Speirs Neumeister, \& Cassady, 2007). Higher rates of introversion among gifted individuals 
(Sak, 2004) indicate a preference for fewer, more intimate friendships than is likely to be the norm. What may appear to others as a problem in developing relationships may actually be the result of a preference to limit the number of relationships cultivated. These endogenous differences and their effect on relationships contribute to the unique lived experience of the gifted individual.

\section{Challenging Environments}

Finding the right level of challenge for gifted individuals in school or the workplace can lead to intense satisfaction and enhance the possibility of building relationships with intellectual peers. Psychologists have observed, however, that a move from an unchallenging environment to one that is a better fit sometimes results in lowered self-esteem. This Big-Fish-Little-Pond-Effect (BFLPE; see Marsh et al., 2008 for a review) results when individuals enter a setting populated by peers with similar or higher academic ability. Even if one takes pride in becoming part of a gifted program or highly regarded think tank, the net effect on the individual's academic selfconcept is negative (Marsh, Kong, \& Hau, 2000). Reduced academic self-concept may lead to reduced motivation to attempt difficult tasks and, thereby, reduce an individual's subsequent level of achievement. Dai and Rinn (2008) cite research indicating that the BFLPE is moderated by individual characteristics, such as entity beliefs - a belief that one's academic abilities affect achievement as compared to a belief in the importance of effort to achievement - and locus of control. While findings of the BFLPE are consistent and widespread, the effect may not be permanent. Ruble and Flett (1988) found that high ability students over time became more focused on autonomous comparison (comparing one's present to past performance) than on social comparison, reducing the BFLPE. Although the BFLPE reduces academic self-concept, it has not been found to affect nonacademic self-concept, suggesting that friendships and activities 
outside the academic realm are not damaged by transition to an appropriate academic setting. It is, however, possible that such transitions will be accompanied by discomfort, academically and socially.

\section{Clinical Issues}

While evidence exists that gifted students do not have higher prevalence rates for the four mental health issues that follow, there are situations only gifted individuals experience that put them, perhaps not at an increased risk, but at a unique risk for developing these disorders. Truly average students will not have experienced chronic heightened expectations from others for performance, nor are they likely to have had multiple outstanding achievements in the past that set the stage for continued expectations and pressures for further outstanding achievement. They will not have been the target of threatening upward comparisons by their peers, or had peers bully or reject them for their exceptional intellectual abilities. Counselors must recognize the unique constellation of abilities and their interaction with social experiences that gifted individuals carry with them into the counseling relationship.

\section{Unhealthy Perfectionism}

Achieving perfection may be the goal of any individual, gifted or not. Some have argued that perfectionism is two-dimensional, with both positive and negative forms (see Stoeber \& Otto, 2006 for a review). There is a counter-literature, however, that dismisses conceptions of an adaptive or healthy perfectionism, considering it instead a disorder (Flett \& Hewitt, 2006; Greenspon, 2000, 2012). Gifted individuals seeking counseling may be experiencing a disordered perfectionism that inhibits normal functioning. According to Greenspon (2012), “as much as perfectionism is about the desire for perfection, its motive force is anxiety-the fear of failure, the sense of never being good enough, and of being somehow flawed" (pp. 600-601). 
The high achiever may pursue excellence through intrinsic motivation or a passion for a subject, with no accompanying anxiety. The perfectionist, however, suffers in the pursuit of excellence.

Hewitt and Flett (1991) conceived of perfectionism as three-dimensional, with each dimension related to the origin of the desire for perfection: self-oriented (expecting perfection of oneself), other-oriented (expecting perfection in others), and socially prescribed (expecting perfection of oneself in response to perceived expectations of society). Although these dimensions may describe an individual's behaviors - for example, being excessively demanding of classmates or coworkers-Greenspon (2012) proposed that the motivation for each is likely to be the same underlying fear of being unacceptable when they or others do not achieve perfection. The anxiety that accompanies perfectionism can be debilitating, leading highly capable individuals to become stuck, avoiding challenging tasks that they fear being unable to adequately complete or suffering from that fear even as they are successful at challenging tasks.

Parker and Mills (1996) found the incidence of perfectionism was not higher among gifted than nongifted middle schoolers. LoCicero and Ashby (2000) found higher levels of adaptive perfectionism and lower levels of maladaptive perfectionism among the gifted than the nongifted middle schoolers in their study. Baker (1996) found only the exceptionally gifted adolescents and some gifted girls in her sample had greater perfectionistic tendencies than their nongifted peers. A performance goal orientation, which is associated with more negative motivation and achievement outcomes than a mastery goal orientation (Elliott \& Dweck, 1988) was related to self-oriented or socially prescribed perfectionism among honors college students in Speirs Neumeister and Finch's (2006) study. Fletcher and Speirs Neumeister (2012) summarized a substantial literature on the relationship between perfectionism and achievement motivation. 
Gifted individuals, even those achieving at high levels, may need counseling to deal with anxiety-producing perfectionism. Because of their exceptional abilities, gifted individuals may perceive pressure from others to achieve what they interpret as perfection. A fear of making mistakes, of not measuring up to others' expectations, of not being good enough, can result in distress (Schuler, 2000). In Schuler's study of gifted middle school aged students, one group of high scorers on a scale of perfectionism reported perfectionistic parents who made their expectations known through frequent criticism, in contrast to another group with average scores, whose parents encouraged them to feel free to make mistakes as they tried to achieve their personal best. For gifted individuals who have experienced frequent success, a fear of failure may grow over time. Orchestrating safe opportunities for failure that will help these individuals overcome their anxiety may be necessary. Choosing an area in which the gifted individual has no particular investment, such as a sport or hobby, is not likely to be harmful to her or his selfconcept (Harter \& Whitesell, 2001).

\section{Anxiety}

Anxiety disorders involve excessive fear in anticipation of a future threat (American Psychiatric Association, 2013). Different from depression, which is typified by sadness, emptiness, or irritability, the anxious individual may experience strong feelings of internal tension, recurring intrusive thoughts, and physical changes such as rapid heart rate or trembling. These responses to an anticipated threat can lead to avoidance behaviors, limiting one's options in relation to the fear-inducing stimulus, which can be social or situational (e.g., specific phobias). Symptoms of anxiety may be chronic, fleeting, or episodic. Chronic anxiety can be debilitating. Episodic anxiety can be no problem, helpful (as when it encourages improved performance), or a problem (as when it interferes with performance or quality of life). Some 
forms of anxiety have a genetic component (American Psychiatric Association, 2013), but environment or experiences are also stimulants of anxiety.

Some have proposed endogenous (internal) characteristics that put gifted individuals at increased risk of mood disorders. Their asynchronous development, perfectionism, overexcitabilities, and high cognitive functioning are pointed to as risk factors (Gross, 1993; Probst \& Piechowski, 2012; Schuler, 2002; Silverman, 2002). There is not, however, empirical evidence of a relationship of these characteristics with anxiety or depression among gifted individuals. A tendency toward neuroticism would lead one to be prone to anxiety, but there is no evidence of higher neuroticism among gifted individuals. Zeidner and Shani-Zinovich (2011), for example, found neuroticism in gifted samples to be lower than that of nongifted samples. Consequently, rather than looking for internal explanations of anxiety, it is more productive to examine how these characteristics come into play in one's environment, with negative outcomes. For example, asynchronous development can lead to anxiety when a child can recognize a problem in her or his environment, yet is powerless to resolve it (Neihart, 2002). The desire to complete a project perfectly may be a response to high expectations of others, putting the gifted individual into a state of anxiety when performance is uncertain.

The lived experience of gifted individuals includes many potential anxiety-producing stressors (Coleman, 2012). They may feel pressures to perform, sometimes from others and sometimes from themselves. Having performed well in the past, they may believe that they must maintain the "top" position to be acceptable to themselves or others (Peterson, 2012).

Overcommitment is a common problem for gifted individuals (Peterson et al., 2009), with complicated schedules and new areas for high expectations, all potential stressors. They may wish to hide their giftedness or even deny it (Swiatek, 2001), which can be stressful when there 
is a fear of being discovered. The threat they present to peers can damage social relationships (Exline \& Lobel, 1999). Constant attention to one's giftedness and others' response to it uses up energy, wastes focus, and creates fear. Even the counseling experience may be anxiety provoking for gifted individuals, when they feel misunderstood or challenged by the counselor. Peterson (2012) reported observing interns needing to be "one up" on their gifted clients (p. 448) and cautions counselors to check their biases and their own insecurities when working with members of this population.

As described previously, gifted individuals live in a world of mixed messages (Cross, 2011), hearing that they should perform their best, yet ostracized, sometimes even bullied (Peterson \& Ray, 2006), when they are too much better than peers. In his experience of psychotherapy with gifted individuals, Grobman (2009) found that his clients had been troubled as children when hearing themselves referred to as "'scary' or 'frighteningly smart'" (p. 120). These mixed messages vary for the nonmodal gifted - the adult gifted female, the rural gifted, ethnic minority, GLBTQ, for example. Clear social norms contribute to certainty in one's environment; mixed messages contribute to uncertainty, which can lead to anxiety. The gifted individual who is highly attuned to his or her environment may feel exceptionally anxious about events or situations of which peers are unaware. High achieving children and adults alike may find themselves unable to ignore potential threats, even far removed.

Medication is a frequent response to symptoms of anxiety. While it may be helpful in some cases of anxiety, particularly those that are chronic or debilitating, counselors and clients should examine the environment for a longer-term solution. A classroom or workplace can vary from calm, to organized with a high level of activity, to chaotic. Each of these settings has the potential to affect the gifted individual differently from his or her peers. When attempting to 
identify the stressors in an anxious client's environment, it is necessary to understand the interaction of giftedness with the setting.

\section{Depression}

Anxiety and depression frequently co-occur and screening for one should typically accompany screening for the other (Neihart, 2012). Whereas internal tensions and heightened physiological response characterize anxiety, "sad, empty or irritable mood, accompanied by somatic and cognitive changes that significantly affect the individual's capacity to function" (American Psychiatric Association, 2013, p. 155) characterize depression. Anxiety may provoke avoidance behaviors through anticipated fear, while depression may result in an inability to engage or disinterest in activities. The response to both may look the same-not engaging in an activity-but the cognitive foundations of the behavior is markedly different.

Both biological and environmental factors may underpin depressive disorders. In the case of gifted individuals and depression, virtually no research has illustrated a genetic predisposition of gifted individuals as a cohort. Moreover, Cross, Cassady, Dixon, and Adams (2008) found that the rates of depression among gifted adolescents were no higher than those of the norming group and Mueller (2009) found they were lower than a nongifted group. Neihart and Olenchak (2002) cited research indicating that the creatively gifted are at increased risk for depression and suicide. Among intellectually gifted individuals, however, it is likely that depression is influenced by environmental factors that can be either the same as the general population or unique to the gifted. The latter is the focus of this discussion.

Depression may be mild and ongoing, deep, or episodic. Depression is a natural aspect of humanness, and eradication is not necessarily a useful objective in treatment. Rather, it is preferable to treat the symptoms of depression, while working towards understanding the causes 
and how an individual responds to different stimuli. Episodic feelings of depression are quite normal, indicating a normal range of affect.

Many of the situations described as anxiety-producing for gifted individuals can also produce depression. Being misunderstood, receiving mixed messages, recognizing potential threats in the environment (to oneself or to others) while helpless to address the problem-all these can lead to hopelessness and depression. The gifted child or adult may be unable to find an appropriately challenging environment. The high school dropouts in Kanevsky and Keighley's (2003) study were responding to a hopeless situation in which schools were simply not meeting their needs for challenge, choice, complexity, control and caring teachers. Their intentional underachievement may have saved them from depression. Boredom is a frequent state of affairs for gifted individuals (Kanevsky \& Keighley, 2003; Peine \& Coleman, 2010). Powerlessness to change this state can easily lead to depression (Taylor, 1989). Overcommitment can lead to overwhelming anxiety and depression, when there is simply too much to be done. Gifted individuals may need support in identifying options that are available to them. Acceleration is one of the most effective, empirically supported interventions for school-aged gifted individuals (Colangelo, Assouline, \& Gross, 2004). Post-secondary education or career change may be appropriate recommendations for the unchallenged gifted adult. Clients may need help in recognizing "where achievement should be located in a hierarchy of factors related to life satisfaction" (Peterson, 2012, p. 448).

\section{Suicidal Behavior and Gifted Individuals}

Despite evidence that gifted individuals have died by suicide (Cross, 2013; Cross, Cook, \& Dixon, 1996; Cross, Gust-Brey, \& Ball, 2002; Hyatt, 2010), prevalence rates for completed suicides among gifted people are not knowable at this time (Cross, 2013). Professionals have 
claimed that certain characteristics of gifted individuals such as unusual sensitivity and perfectionism (Delisle, 1986) and isolation that is a function of extreme introversion (Kaiser \& Berndt, 1985) are associated with suicidal behavior, but there is no concrete evidence of an increased risk. National suicide statistics record no indication of giftedness. Moreover, the research base has very few studies on the suicidal behavior of gifted individuals, and these tend to be very small scale studies, studies with nonrepresentative samples, or indirect studies (GustBrey \& Cross, 1999).

Suicidal behaviors exist as ideation, gestures, attempts, and completions. Ideation research has become a window into the broader suicide phenomenon. Cross, Cassady, and Miller (2006) found suicide ideation occurs at a rate about the same or slightly lower for gifted adolescents when compared to a norm group. Despite this similarity, the factor structure for suicide ideation differs between gifted students and the norm group (Cassady \& Cross, 2006). In the norm group, a three factor solution was found, with (a) wishes and plans to commit suicide, (b) focus on the responses and aspects of others, and (c) morbid ideation. For gifted adolescents, a four-factor solution was found, with (a) Suicide Pragmatics, (b) Morbid Fixation, (c) Social Impact, and (d) Social Isolation. The difference in the two models suggests a more complicated intellectual interpretation is ongoing when gifted individuals engage in suicide ideation. This qualitative difference in suicide ideation indicates that traditional emphases in counseling will need to be adjusted. Cassady and Cross (2006) made the following suggestions in keeping with the structure of beliefs of gifted adolescents:

Those adolescents with high endorsement of the Suicide Pragmatics are those most likely in need of intensive observation and scrutiny, ensuring that the tools and opportunity for suicide are removed from the individual. Adolescents who show high endorsement of the 
Social Isolation items may benefit from direct intervention focused on improving selfesteem, relief from depression, or simple counseling on social interactions. Those with high scores on the Social Impact factor may benefit more from interventions focused on the realistic outcomes of death and suicide in the public eye. (p. 302)

Given that research has demonstrated a higher rate of introverts among gifted individuals than in the general population (Sak, 2004), issues related to suicidal behavior and isolationism (often associated with introversion) among gifted individuals are to be expected.

Gifted individuals may have greater success when attempting suicide than their nongifted peers (Cross, 2013). In the general population, "suicide attempts are substantially more common than completed suicides by a factor between 10 and 20" (National Center for Biotechnology Information, 2013). In five psychological autopsies of gifted individuals who died by suicide, three were successful on their first attempt (Cross, Cook, \& Dixon, 1996; Cross, Gust-Brey, \& Ball, 2002; Hyatt, 2010). After years of research with gifted individuals, Cross (2013) expressed a concern that gifted people may be more successful in their suicide attempts. If accurate, actual prevalence rates could soar beyond those of nongifted peers. Should future research corroborate this observation, this would substantiate that being gifted places individuals at a higher risk rate for suicide completion. To date, the research on suicide ideation leads one to the opposite conclusion.

The progression from suicidal thoughts to action is not a direct or certain path (Cross, 2013). Individuals are buoyed by protective factors that can lift them out of depression (e.g., supportive relationships) or can be weighed down by risk factors (e.g., alcohol and/or drug use) that can lead to greater hopelessness and even action (White, 2010). Counselors must directly challenge individuals — gifted or nongifted—about specific thoughts they may be having of 
killing themselves. Allowing them to evade the issue does nothing to reduce the exacerbation of perturbation and constriction of intellectual focus (Shneidman, 1996), which encourage thoughts of cessation (death) as the only answer to their problems. Counselors should learn what risk factors are present in a client's life and encourage the removal of as many of these as possible. For suicidal gifted individuals, unique risk factors such as pressure from others or themselves to achieve, self-oriented or socially prescribed perfectionism, difficulties in family or peer relationships due to one's giftedness, the challenge of mixed messages, are additional concerns that must be considered. Ideation in the presence of risk factors can turn quickly into irreversible action.

Counselors must understand that many gifted people lead their lives feeling different (aberrant) from other people, that they feel they must hide who they really are in order to be accepted, or that they must engage in social coping strategies not to stand out. For many gifted people, their coping approach is to be their skill set or talent; to exist only within the protected role. Challenges to that role, such as a transition to a more appropriate academic setting or an unexpected low grade, can be devastating. Given this lived experience, when a gifted person gets caught up in the suicidal spiral, their unique lived experience in addition to any of the other risk factors for suicidal behavior add up to a particularly threatening situation.

Gifted individuals may be reluctant to seek support in times of psychological need, believing they should be able to resolve any problems with their high abilities, that counselors do not have time for those who are successful in comparison with peers, or because they want to protect their successful image (Peterson, 2012, Peterson \& Ray, 2006). Counselors should not assume that the appearance of well-being means there are no problems under the surface. Peterson (2012) recommended "counselors take seriously whatever is presented as concerns, 
including by parents, even when it does not appear at first glance to rise to the level of urgency" (p. 452). Because the research base specific to gifted individuals and suicide is in its early stages, counselors can utilize traditional predictors of suicide for the general population, plus the important aspects of the individual's lived experience, to help them. Aberrant or highly unusual behavior should not be tolerated under the guise of gifted behavior (Cross, Cook, \& Dixon, 1996). When in doubt, do something.

\section{Counseling Needs Unique to Gifted Individuals}

Gifted individuals face unique psychological challenges due to their exceptional abilities. Some of these are endogenous (e.g., personality, need for cognition, perfectionism, etc.) and some exogenous (e.g., anti-intellectual or unchallenging environment). The lived experience of the gifted may be profoundly different from their average peers-the majority of society (Coleman, 2012). When professionals are unaware of the social and emotional needs and characteristics of gifted individuals, they may inadvertently do more harm than good. Misdiagnosis of overexcitabilities, for example, as ADHD can lead to inappropriate medical treatment and pathologizing of what are normal behaviors in a gifted individual (Amend \& Peters, 2012). It is necessary to consider explanations for the presenting problem through the lens of giftedness in order to see possibilities outside the realm of pathology. Is anxiety or depression the result of an inappropriate academic placement or of difficulties with interpersonal relationships brought about by one's giftedness? On the other hand, are aberrant behaviors being ignored or accepted as gifted behaviors? When misdiagnosis occurs, a solution is unlikely to be successful and may actually be harmful. Without considering giftedness as part of the equation, the correct solution will not be found for these individuals. 
An environment that does not respond to a gifted individual's needs by providing adequate intellectual stimulation can be the source of depression. Being required, as a child or adult, to spend each day in a boring setting from which there is no escape, could lead anyone to become depressed. The difference for the gifted individual is that every other person in that setting may be adequately challenged and stimulated. Only the gifted individual suffers. The exceptionally gifted person will have even more frequent experiences like this, unless accommodations are made or she or he learns how to alter her or his own environment. Peine and Coleman (2010) found that some gifted students developed strategies for dealing with the frequent waiting they did in school, reading ahead (when allowed), drawing, or daydreaming. In contrast to the planned learning activities in which they could have been engaged, these strategies are unsatisfactory, probably to the student and teacher alike, but they helped the children make it through the boredom. Adults unchallenged in the workplace may need to develop strategies that are more productive in order to stay engaged. Changing environments may be the most effective way to deal with this lack of stimulation. Children may be accelerated a grade (or multiple grades); adults may consider job or even career changes to find the right environment.

Social relationships are key to positive mental health (Baumeister \& Leary, 1995). The social isolation gifted individuals may feel due to their differentness can be harmful to their wellbeing. It is imperative that gifted individuals have an opportunity to build healthy social relationships. This may be one friend or many; same-age, older, or younger (Cross, 2012). Age mates may not have common interests or similar intellectual ability. Due to their asynchronous development or early rejection by peers, some gifted individuals will not have well-developed social skills and may need direct teaching to learn how they may effectively approach and 
engage with others (Webb, Gore, Amend, \& DeVries, 2007). Healthy social coping strategies, such as offering to help peers or engaging in extracurricular activities, will help adolescents deal with the stigma of giftedness. Students who deny the impact of their giftedness on peer relationships may benefit by learning these problem-focused strategies. The goal is to assist the gifted individual in building positive social supports that can serve as a buffer when difficult experiences occur.

\section{Conclusion}

As the research considering the psychology of gifted individuals has expanded, so has the ability to anticipate and provide increasingly efficacious strategies to assist them. Recognizing the unique experiences and characteristics of gifted individuals is necessary to supporting them in the treatment of unhealthy perfectionism, anxiety, depression, or suicidality.

The challenge for providing effective counseling to gifted students is the fact that the presenting problems leading the gifted person to counseling may be deeply intertwined with other variables not typical of the average developmental patterns of nongifted clients. Therefore, the counselor must understand the myriad ways in which gifted people experience life differently from the general population and, as Feldman (1991) has pointed out from his research, the ways that nonuniversal developmental patterns emerge as gifted people develop within differing talent domains. Simply stated, the role of professional counselors is to apply training that emphasizes typical developmental patterns to those who do not develop typically. Neglecting a client's giftedness when making a diagnosis or in designing appropriate treatment may be harmful to the gifted individual. It is important for counselors to know the diverse characteristics of gifted individuals and the environmental factors that may affect them in order to successfully promote their well-being. 


\section{References}

Amend, E. R., \& Peters, D. B. (2012). Misdiagnosis and missed diagnosis of gifted children: The importance of accurate assessment. In T. L. Cross \& J. R. Cross (Eds.), Handbook for counselors serving students with gifts and talents (pp. 585-596). Waco, TX: Prufrock Press.

American Psychiatric Association. (2013). Diagnostic and statistical manual of mental disorders, $5^{\text {th }}$ ed. Washington, DC: American Psychiatric Publishing.

Baker, J. (1996). Everyday stressors of academically gifted adolescents. Journal of Secondary Gifted Education, 7, 356-368.

Baumeister, R. F., \& Leary, M. R. (1995). The need to belong: Desire for interpersonal attachments as a fundamental human motivation. Psychological Bulletin, 117, 497-529. doi: 10.1037/0033-2909.117.3.497

Berndt, T. J. (1999). Friends' influence on students' adjustment to school. Educational Psychologist, 34, 15-28. doi: 10.1207/s15326985ep3401_2

Burney, V. H., \& Cross, T. L. (2006). Impoverished students with academic promise in rural settings: 10 Lessons from Project Aspire. Gifted Child Today, 29(2), 14-21.

Cacioppo, J. T., Petty, R. E., \& Kao, C. F. (1984). The efficient assessment of need for cognition. Journal of Personality Assessment, 48, 306-307. doi: 10.1207/s15327752jpa4803_13

Cassady, J. C., \& Cross, T. L. (2006). A factoral representation of gifted adolescent suicide. Journal for the Education of the Gifted, 29(3), 290-304.

Colangelo, N., Assouline, S., \& Gross, M. (2004). A nation deceived: How schools hold back America's brightest students, Vol. I \& Vol. II. Iowa City, IA: The University of Iowa.

Coleman, L. J. (1985). Schooling the gifted. Menlo Park, NJ: Addison-Wesley. 
Coleman, L. J. (2012). Lived experience, mixed messages, and stigma. In T. L. Cross \& J. R. Cross (Eds.), Handbook for counselors serving students with gifts and talents (pp. 371392). Waco, TX: Prufrock Press.

Coleman, L. J., \& Cross, T. L. (1988). Is being gifted a social handicap? Journal for the Education of the Gifted, 11, 41-56.

Coleman, L. J., \& Cross, T. L. (2000). Social-emotional development and the personal experience of giftedness. In K. Heller, F. Mönks, R. Sternberg, \& R. Subotnik (Eds.), International handbook of giftedness and talent (pp. 203-212). Oxford, England: Elsevier Science.

Cross, J. R. (2012). Peer relations. In T. L. Cross \& J. R. Cross (Eds.), Handbook for counselors serving students with gifts and talents (pp. 409-426). Waco, TX: Prufrock Press.

Cross, T. L. (2011). On the social and emotional lives of gifted children (4 ${ }^{\text {th }}$ ed.). Waco, TX: Prufrock Press.

Cross, T. L. (2013). Suicide among gifted children and adolescents: Understanding the suicidal mind. Waco, TX: Prufrock Press

Cross, T. L., Cassady, J. C., Dixon, F. A., \& Adams, C. M. (2008). The psychology of gifted adolescents as measured by the MMPI-A. Gifted Child Quarterly, 52, 326-339. doi: $10.1177 / 0016986208321810$

Cross, T. L., Cassady, J. C., \& Miller, T. (2006). Suicidal ideation and psychological type in gifted adolescents. Gifted Child Quarterly, 19, 46-48.

Cross, T. L., Coleman, L. J., \& Stewart, R. A. (1995). Psychosocial diversity of gifted adolescents: An exploration of the stigma of the giftedness paradigm. Roeper Review, 17, 181-185. doi: 10.1080/02783199509553655 
Cross, T. L., Coleman, L. J., \& Terhaar-Yonkers, M. (1991). The social cognition of gifted adolescents in schools: Managing the stigma of giftedness. Journal for the Education of the Gifted, 15, 44-55.

Cross, T. L., Cook, R. S., \& Dixon, D. N. (1996). Psychological autopsies of three academically talented adolescents who committed suicide. Journal of Secondary Gifted Education, 7, 403-409.

Cross, T. L., Gust-Brey, K., \& Ball, P. B. (2002). A psychological autopsy of the suicide of an academically gifted student: Researchers' and parents' perspectives. Gifted Child Quarterly, 46, 247-264. doi: 10.1177/001698620204600402

Cross, T. L., Speirs Neumeister, K. L., \& Cassady, J. C. (2007). Psychological types of academically gifted adolescents. Gifted Child Quarterly, 51, 285-294. doi: $10.1177 / 0016986207302723$

Dabrowski, K. (1964). Positive disintegration. Boston, MA: Little, Brown.

Dai, D. Y., \& Rinn, A. N. (2008). The big-fish-little-pond effect: What do we know and where do we go from here? Educational Psychological Review, 20, 283-317. doi: $10.1007 / \mathrm{s} 10648-008-9071-\mathrm{x}$

Delisle, J. (1986). Death with honors: Suicide among gifted adolescents. Journal of Counseling \& Development, 64, 558-566. doi: 10.1002/j.1556-6676.1986.tb01202.x

Elliott, E. S., \& Dweck, C. S. (1988). Goals: An approach to motivation and achievement. Journal of Personality and Social Psychology, 54, 5-12. doi: 10.1037/0022-3514.54.1.5

Exline, J. J., \& Lobel, M. (1999). The perils of outperformance: Sensitivity about being the target of a threatening upward comparison. Psychological Bulletin, 125, 307-337. doi: 10.1037/0033-2909.125.3.307 
Farmer, T. W., \& Farmer, E. M. Z. (1996). Social relationships of students with exceptionalities in mainstream classrooms: Social networks and homophily. Exceptional Children, 62, 431-435.

Farmer, T. W., \& Hollowell, J. H. (1994). Social networks in mainstream classrooms: Social affiliations and behavioral characteristics of students with emotional and behavioral disorders. Journal of Emotional and Behavioral Disorders, 2, 143-155

Feldman, D. H. (with Goldsmith, L. T.). (1991). Nature's gambit: Child prodigies and the development of human potential. New York, NY: Teachers College Press. (Original work published 1986)

Festinger, L. (1954). A theory of social comparison processes. Human Relations, 7, 117-140. doi: $10.1177 / 001872675400700202$

Fletcher, K. L., \& Speirs Neumeister, K. L. (2012). Research on perfectionism and achievement motivation: Implications for gifted students. Psychology in the Schools, 49, 668-677. doi: $10.1002 /$ pits. 21623

Flett, G. L., \& Hewitt, P. L. (2006). Positive versus negative perfectionism in psychopathology: A comment on Slade and Owens's Dual Process Model. Behavioral Modification, 30, 472-495. doi: $10.1177 / 0145445506288026$

Greenspon, T. S. (2000). 'Healthy perfectionism' is an oxymoron! Reflections on the psychology of perfectionism and the sociology of science. Journal of Secondary Gifted Education, 11, 197-208.

Greenspon, T. S. (2012). Perfectionism: A counselor's role in a recovery process. In T. L. Cross \& J. R. Cross (Eds.) Handbook for counselors serving students with gifts and talents (pp. 597-613). Waco, TX: Prufrock Press. 
Grobman, J. (2009). A psychodynamic psychotherapy approach to the emotional problems of exceptionality and profoundly gifted adolescents and adults: A psychiatrist's experience. Journal for the Education of the Gifted, 33, 106-125.

Gross, M.U.M. (1993). Exceptionally gifted children. London, UK: Routledge. doi: $10.4324 / 9780203315378$

Gust-Brey, K., \& Cross, T. L. (1999). An examination of the literature base on the suicidal behaviors of gifted students. Roeper Review, 22, 28-35. doi: $10.1080 / 02783199909553994$

Harter, S., \& Whitesell, N. R. (2001). On the importance of importance ratings in understanding adolescents' self-esteem: Beyond statistical parsimony. In R. J. Riding \& S. G. Rayner (Eds.), Self-perception (pp. 3-23). Westport, CT: Ablex.

Hermann, K. M., \& Lawrence, C. (2012). Family relationships. In T. L. Cross \& J. R. Cross (Eds.), Handbook for counselors serving students with gifts and talents (pp. 393-407). Waco, TX: Prufrock Press.

Hewitt, P. L., \& Flett, G. L. (1991). Perfectionism in the self and social contexts: Conceptualization, assessment, and association with psychopathology. Journal of Personality and Social Psychology, 60, 456-470. doi: 10.1037/0022-3514.60.3.456

Hyatt, L. (2010). A case study of the suicide of a gifted female adolescent: Implications for prediction and prevention. Education, 33, 514-535.

Kaiser, C.F., \& Berndt, D. J. (1985). Predictors of loneliness in the gifted adolescent. Gifted Child Quarterly, 29, 74-77. doi: 10.1177/001698628502900206

Kanevsky, L., \& Keighley, T. (2003). To produce or not to produce? Understanding boredom and the honor in underachievement. Roeper Review, 26, 20-28. doi: 


\section{$10.1080 / 02783190309554235$}

LoCicero, K. A., \& Ashby, J. S. (2000). Multidimensional perfectionism in middle school age gifted students: A comparison to peers from the general cohort. Roeper Review, 22, 182185. doi: 10.1080/02783190009554030

Luftig, R. L., \& Nichols, M. L. (1990). Assessing the social status of gifted students by their age peers. Gifted Child Quarterly, 34, 111-115. doi: 10.1177/001698629003400305

Marsh, H. W., Kong, C.-K., \& Hau, K.-T. (2000). Longitudinal multilevel models of the bigfish-little-pond effect on academic self-concept: Counterbalancing contrast and reflectedglory effects in Hong Kong schools. Journal of Personality \& Social Psychology, 78, 337-349. doi: 10.1037/0022-3514.78.2.337

Marsh, H. W., Seaton, M., Trautwein, U., Lüdtke, O., Hau, K. T., O’Mara, A. J., \& Craven, R. G. (2008). The big-fish-little-pond-effect stands up to critical scrutiny: Implications for theory, methodology, and future research. Educational Psychology Review, 20, 319-305. doi:10.1007/s10648-008-9075-6

Martin, L. T., Burns, R. M., \& Schonlau, M. (2010). Mental disorders among gifted and nongifted youth: A selected review of the epidemiologic literature. Gifted Child Quarterly, 54, 31-41. doi:10.1177/0016986209352684

Meijs, N., Cillessen, A. H. N., Scholte, R. H. J., Segers, E., \& Spijkerman, R. (2008). Social intelligence and academic achievement as predictors of adolescent popularity. Journal of Youth and Adolescence, 39, 62-72. doi: 10.1007/s10964-008-9373-9

Mendaglio, S. (2012). Overexcitabilities and giftedness research: A call for a paradigm shift. Journal for the Education of the Gifted, 35, 207-219. doi: 10.1177/0162353212451704 
Moon, S. M., Jurich, J. A., \& Feldhusen, J. F. (1998). Families of gifted children: Cradles of development. In R. Friedman (Ed.), Talent in context: Historical and social perspectives (pp. 81-100). Washington, DC: American Psychological Association. doi: $10.1037 / 10297-005$

Mueller, C. E. (2009). Protective factors as barriers to depression in gifted and nongifted adolescents. Gifted Child Quarterly, 53, 3-14. doi:10.1177/0016986208326552v

National Center for Biotechnology Information (2013). Suicide attempts and suicide completions. Retrieved from http://www.ncbi.nlm.nih.gov/books/NBK42886/

Neihart, M. (2002). Gifted children and depression. In M. Neihart, S. M. Reis, N. M. Robinson, \& S. M. Moon (Eds.), The social and emotional development of gifted children: What do we know? (pp. 93-102). Waco, TX: Prufrock Press.

Neihart, M. (2012). Anxiety, depression, and resilience. In T. L. Cross \& J. R. Cross (Eds.), Handbook for counselors serving students with gifts and talents (pp. 615-630). Waco, TX: Prufrock Press.

Neihart, M., \& Olenchak, F. R. (2002). Creatively gifted children. In M. Neihart, S. M. Reis, N. M. Robinson, \& S. M. Moon (Eds.), The social and emotional development of gifted children: What do we know? (pp. 165-176). Waco, TX: Prufrock Press.

Parker, W. D., \& Mills, C. J. (1996). The incidence of perfectionism in gifted students. Gifted Child Quarterly, 40, 194-199. doi: 10.1177/001698629604000404

Peine, M., \& Coleman, L. (2010). The phenomenon of waiting in class. Journal for the Education of the Gifted, 34, 220-244. 
Peterson, J. S. (2012). The counseling relationship. In T. L. Cross \& J. R. Cross (Eds.), Handbook for counselors serving students with gifts and talents (pp. 443-460). Waco, TX: Prufrock Press.

Peterson, J. S., Duncan, N., \& Canady, K. (2009). A longitudinal study of negative life events, stress, and school experiences of gifted youth. Gifted Child Quarterly, 53, 34-49. doi: $10.1177 / 0016986208326553$

Peterson, J. S., \& Ray, K. E. (2006). Bullying among the gifted: The subjective experience. Gifted Child Quarterly, 50, 148-168. doi: 10.1177/001698620605000305

Piechowski, M. M. (1999). Overexcitabilities. In M. A. Runco \& S. R. Pritzker (Eds.), Encyclopedia of creativity (Vol. 2, pp. 325-334). San Diego, CA: Academic Press.

Probst, B., \& Piechowski, M. (2012). Overexcitabilities and temperament. In T. L. Cross \& J. R. Cross (Eds.), Handbook for counselors serving students with gifts and talents (pp. 443460). Waco, TX: Prufrock Press.

Quatman, T., \& Swanson, C. (2002). Academic self-disclosure in adolescence. Genetic, Social, and General Psychology Monographs, 128, 47-75.

Robinson, N. (1996). Counseling agendas for gifted young people: A commentary. Journal for the Education of the Gifted, 20, 128-137.

Ruble, D. N., \& Flett, G. L. (1988). Conflicting goals in self-evaluative information seeking: Developmental and ability level analyses. Child Development, 59, 97-106. doi: $10.2307 / 1130392$

Sak, U. (2004). A synthesis of research on psychological type of gifted adolescents. Journal of Secondary Gifted Education, 15, 70-79.

Schuler, P. A. (2000). Perfectionism and gifted adolescents. Journal of Secondary Gifted 
Education, 11(4), 183-196.

Schuler, P. A. (2002). Perfectionism in gifted children and adolescents. In M. Neihart, S. M.

Reis, N. M. Robinson, \& S. M. Moon (Eds.), The social and emotional development of gifted children: What do we know? (pp. 71-80). Waco, TX: Prufrock Press.

Semrud-Clikeman, M. (2007). Social competence in children. New York, NY: Springer. doi: http://dx.doi.org/10.1007/978-0-387-71366-3_1

Shneidman, E. S. (1996). The suicidal mind. Oxford, England: Oxford University Press.

Silverman, L. K. (2002). Asynchronous development. In M. Neihart, S. M. Reis, N. M. Robinson, \& S. M. Moon (Eds.), The social and emotional development of gifted children: What do we know? (pp. 31-40). Waco, TX: Prufrock Press.

Speirs Neumeister, K. L., \& Finch, H. (2006). Perfectionism in high-ability students: Relationship precursors and influences on achievement motivation. Gifted Child Quarterly, 50, 238-251. doi:10.1177/001698620605000304

Stoeber, J. (2013, November 10). How other-oriented perfectionism differs from self-oriented and socially prescribed perfectionism. Journal of Psychopathology and Behavioral Assessment, no pagination specified. doi:10.1007/s10862-013-9397-7

Stoeber, J., \& Otto, K. (2006). Positive conceptions of perfectionism: Approaches, evidence, challenges. Personality and Social Psychology Review, 10, 295 - 319. doi:10.1207/s15327957pspr1004 2

Swiatek, M. A. (2001). Social coping among gifted high school students and its relationship to self-concept. Journal of Youth and Adolescence, 30, 19-39. doi: 10.1023/A:1005268704144

Taylor, S. E. (1989). Positive illusions: Creative self-deception and the healthy mind. New York, 
NY: BasicBooks.

Van Manen, M. (1990). Researching lived experience: Human science for an action sensitive pedagogy. Albany, NY: SUNY Press.

Webb, J. T. (1993). Nurturing the social-emotional development of gifted children. In K. A. Heller, F. J., Mönks, \& A. H. Passow (Eds.), International handbook of research and development of giftedness and talent (pp. 525-538). Oxford, UK: Pergamon Press.

Webb, J. T., Gore, J. L., Amend, E. R., \& DeVries, A. R. (2007). A parent's guide to gifted children. Scottsdale, AZ: Great Potential Press.

White, J. (2010). Risk and protective factors. Retrieved from http://www.mcf.gov.bc.ca/ suicide_prevention/protective_factors.htm

Zeidner, M., \& Shani-Zinovich, I. (2011). Do academically gifted and nongifted students differ on the Big-Five and adaptive status? Some recent data and conclusions. Personality and Individual Differences, 51, 566-570. doi: 10.1016/j.paid.2011.05.007 